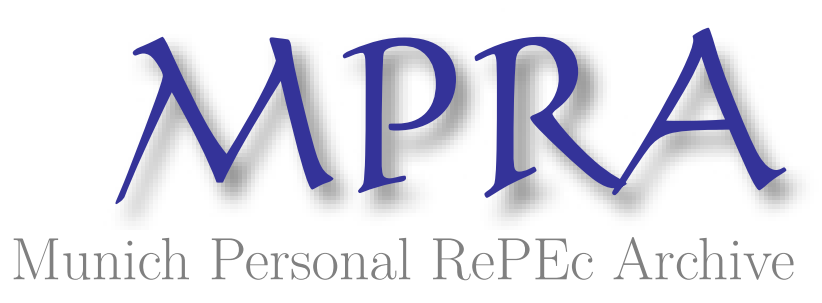

\title{
Global imbalances and household savings: the role of wealth
}

Salotti, Simone

University of Siena

2008

Online at https://mpra.ub.uni-muenchen.de/17729/

MPRA Paper No. 17729, posted 08 Oct 2009 15:05 UTC 


\title{
GLOBAL IMBALANCES AND HOUSEHOLD SAVINGS: THE ROLE OF WEALTH
}

\author{
Simone Salotti ${ }^{*}$
}

\begin{abstract}
Many claim that fluctuations in US private savings help to create and to sustain global imbalances because of their influence on the current account deficit. To test this claim, this paper investigates the determinants of aggregate household savings using a panel of 18 developed countries for the period 1980-2005. We weave two strands of literature: the first strand from consumer theory, considering specifically the 'wealth effect', the second strand from aggregate private savings theory. The original contribution of this paper derives from the main explanatory variables of the household savings function: two measures of household wealth, the first a financial variable and the second a variable for tangible/housing stock. The salience of these variables has not been tested before. The model is then enriched with variables taken from the private savings literature. To find the best technique to estimate the long run savings function, unit root and cointegration tests are carried out, from which evidence of a cointegrating relationship is found. The group means FMOLS is used to estimate the model. The empirical evidence suggests effects consistent with theory: an increase in wealth negatively affects household savings. Furthermore, when important explanatory variables, such as government savings and population dependency ratios, are included in the model, tangible wealth becomes the only kind of wealth to (weakly and negatively) influence household savings in developed countries. In the US however, wealth does not seem to affect household savings negatively, it seems instead that government savings and population changes better explain the decline of savings during the past two decades. This finding provides additional evidence on the issue of global imbalances, and suggests that the recent booms of the stock and the real estate markets should not be blamed for the decline in US household and private savings.
\end{abstract}

JEL: E21, C23

Keywords: Household Savings, Wealth Effect, Panel Cointegration, Global Imbalances, Life Cycle Model.

\footnotetext{
‘ salotti@unisi.it Department of Economics - University of Siena - P.za San Francesco 7 - 53100 - Siena (Italy)
} 


\section{Introduction}

Since the 1980s the household savings rates in many developed countries have dramatically decreased. The current negative savings rate in the US seems to play a particularly important role in the development of so-called "global imbalances" due to the effect of savings on the US current account deficit. The term "global imbalances" refers to the fundamental imbalance in the global balance of payments, where a widening US current account deficit sees its counterpoint in the surpluses run by a number of countries - mostly East-Asian and oil exporting countries. This scenario has raised some concerns about long-term sustainability and about the possibility of disorderly adjustments. Many observers have called for a coordinated policy response to the problem (for instance, Eichengreen, 2006). ${ }^{1}$ According to simple accounting identities, a current account deficit necessarily equals capital inflows to the country. Therefore it equals the negative difference between domestic savings and investments. Hence, global imbalances have often been studied by analyzing saving and investment, both from a global perspective and from a US perspective. ${ }^{2}$ Two facts emerge. First, a global savings glut has resulted in funds being channeled to the United States and these funds have financed the United States' large current account deficit. Second, a drop in national saving in the United States is at the root of its current account imbalances.

Regarding the second point, even authors with different ideological perspectives agree that the decline in US private savings is rooted in the increase in households' net worth, which grew as a consequence of the stock market boom up to 2000 and the real estate pricing boom thereafter. For example, Feldstein (2008) and Chandrasekhar and Ghosh (2005) hypothesize that a future increase in US savings would rely on real estate market behavior, where lower prices could lead to an increase in savings rates. Their reasoning is based on the "wealth effect" from standard consumer theory. According to this mechanism, an increase in wealth is followed by an increase in consumption (and a decrease in savings) because changes in wealth directly affect households' contemporaneous budget sets. But, the reasoning that links an increase in prices to a decline in savings ignores a strand of literature on private savings that predominantly disregards wealth when analyzing the determinants of savings. Moreover, the decline in both private and household savings rates began long before the booms that are claimed to have caused them, which casts doubt on the validity of such a univocal explanation.

\footnotetext{
${ }^{1}$ However, some researchers do not agree on the need for rebalancing actions, feeling that the system is perfectly capable of sustaining such imbalances even in the long run (for instance, Gray, 2004, writes about the possible exhaustion of the international role of the US dollar; Dooley et al., 2005, discuss the Bretton Woods II regime).

${ }^{2}$ From a global perspective, Bernanke (2005), Summers (2004), and Truman (2004); from a US perspective, Roubini and Setser (2004), Faulkner-MacDonagh (2003); sometimes attempts to combine those two perspectives have been made, as in Terrones and Cardarelli (2005).
} 
Declining saving rates critically affect global imbalances. We therefore need to better understand household savings to explain more adequately the role that they play in creating global imbalances. As Eichengreen $(2006,16)$ asserts, "we know relatively little about how the standard policy variables affect household saving, the component of private saving that has fallen most dramatically in recent years." If action is to be taken, it is important to reach a deeper understanding of what determines savings and consequently to understand how changes in these determinants caused savings to decline. The reasons may lie in financial and housing markets behavior, in fiscal policy, or in demographic changes.

We aim to achieve a better understanding of what drives aggregate household savings, based on a detailed empirical analysis for which we estimate a long run savings function. Using intuitions from the literature on consumer theory, two measures of financial and tangible/housing wealth usually excluded from regression analysis constitute our two main explanatory variables. We collected data for financial wealth from a number of different national sources, while the measure of tangible/housing wealth has been constructed for all the countries in the panel thanks to several kinds of data, building on research by Case et al. (2005). The other explanatory variables are consistent with theory and with the empirical literature on private savings. Most previous studies are based on Modigliani's life-cycle savings hypothesis, which models individual consumption patterns. It seems more plausible, therefore, to test the model using household savings as the dependent variable and to leave aside corporate savings, which is the other component of private savings. Yet corporate savings are probably governed by considerations potentially irrelevant to individual household savings. Furthermore, we check whether explanatory variables conventionally used to study private savings are relevant to household savings. Finally, the methods adopted in this paper provide further support for panel data cointegration techniques to analyze savings on the basis of accurate unit root and cointegration tests.

In line with theory, the main results show that tangible/housing wealth and government savings in developed countries between 1980 and 2005 had significantly negative effects on household savings. Contrary to theory, we find no evidence of a similar negative effect of financial wealth. This is unsurprising since the previous literature usually shows that financial wealth has smaller effects on consumption. Consistent with expectations, the data displays heterogeneity among the countries in the sample. The USA provides the most surprising result - it seems that tangible/housing wealth has a positive effect on household savings, contrary to theory and contrary to the previous evidence on the wealth effect. We hypothesize that this could be the result of two opposing effects of from the two different cohorts of individuals. The first group comprises households who own homes, and for whom increased housing wealth could exert a negative effect 
on savings. The second group comprises households intending to buy homes in the future, and for whom rising housing prices could positively affect savings. In fact, "increasing house prices can trigger a variety of responses, in particular from young owners or prospective future homeowners" (Bertola and Hochguertel, 2007, 138). However, this result calls for further research, possibly using household level data.

The rest of the paper is organized as follows. Section 2 provides an overview of the existing literature, as well as a description of the recent developments in savings rates in developed countries. Section 3 discusses the determinants of savings suggested by theory and by empirical evidence, and describes the dataset and the empirical strategy followed in the analysis. Section 4 presents the estimation results. Section 5 concludes briefly.

\section{Private and household savings: stylized facts and previous literature}

\subsection{Stylized facts}

Private saving rates have fallen considerably in several high income countries during the last 25 years, as shown in Figure 1. This phenomenon has attracted great attention and several economists have dedicated studies to understand the underlying causes of private savings. For a high number of developed countries, aggregate household savings rates present similar patterns. But, aggregate savings have not been studied as deeply as private savings. Figure 2 shows that in 11 countries out of the 18 OECD sample countries the decline in household savings rates has been a significant phenomenon.

De Serres and Pelgrin (2003) state that the decline in private savings rates in most of the countries coincided with an increase in household financial net worth, but they only provide data for a few countries. They also add $(2003,119)$ that "even in countries where private saving rates have fallen to particularly low levels, the decline seems to be mostly accounted for by determinants that do not include measures of financial or housing wealth and that have themselves evolved in a sustainable way."

Our paper puts this statement to the test, presenting new empirical evidence about the importance of wealth on savings when other determinants are taken into account. The benchmark theoretical model for explaining private savings behavior is the life-cycle model originally proposed by Ando and Modigliani (1963) and extended by Jappelli and Pagano (1994). This model shows that people save when young to finance consumption when retired. With no bequests, the dissavings of the old should offset the savings of the young, with the result of no aggregate savings in a stable population. This status quo can change when the age structure of the population is unbalanced or if the economy experiences high growth that makes the incomes of the young relatively higher than 
the retirement income of the old. But, this simple model alone could not explain the various and variable private savings rates across the world. Hence, several additional possible determinants have been proposed and most of them have been used in previous econometric models. Household wealth has also been proposed as an explanatory variable, but it has been rarely tested empirically due to problems in finding reliable data. Even if the model explains household savings, the previous literature has always studied aggregate private savings, that include corporate savings. But, corporate savings are probably driven by different considerations than household savings. ${ }^{3}$ In this paper, we focus on household savings, providing an important new contribution.

\subsection{The empirical literature}

The existing empirical literature on aggregate savings makes use of various ways to study the determinants of savings: static or dynamic model specifications, a wide range of explanatory variables, and different estimation techniques. Moreover, while the seminal studies tested static models with a large number of regressors (Edwards, 1995, Loayza et al., 2000), after a pathbreaking paper by Haque et al. (1999), dynamic models and heterogeneous panel estimators are now thought to fit the data better and are used in the majority of studies. ${ }^{4}$

Haque et al. (1999) re-examined the existing empirical literature, finding that the regression results neglected heterogeneity and dynamics, which had both influenced the results. By estimating a model with most of the variables already studied in the literature (including those suggested by the life-cycle model), they conclude $(1999,22)$ that "the fiscal variables (...) are the key determinants of private savings rates in the industrial countries in the post world war II period."

Since then, new techniques have been used to estimate models capable of explaining the behavior of private savings. Most of the scholars exploited the existence of a stable long run relationship among the main variables, either writing the model in an error correction form or using panel cointegration techniques. For example, Ferrucci and Miralles (2007) and De Serres and Pelgrin (2003) use the Pooled Mean Group (PMG) estimator developed by Pesaran et al. (1999); Sarantis and Stewart

\footnotetext{
${ }^{3}$ The usual justification for the use of private savings instead of household savings is that there is a perfectly negative correlation between household savings and corporate savings. Ferrucci and Miralles (2007, 11) argue as follows, "Although the offset is generally found to be less than one for one, the finding that household saving indeed reacts to corporate saving seems to be sufficiently well documented to allow focusing this study on aggregate private saving." However, we tested the correlation between those two variables at a country level in our panel and, though we found a significant and negative correlation in 13 out of 18 countries, the coefficient was greater than -0.5 in only half of the countries. To concentrate on household savings, instead of limiting the study to private savings, was considered worthwhile.

${ }^{4}$ Another part of the literature concentrates on studying more deeply the effects of single variables, which are claimed to be more important than others. Two notable examples are Heer and Süssmuth (2006), who find no evidence of a negative effect of inflation on savings in the US, claiming that the role of this variable should be revised at a theoretical level. Another is Bloom et al. (2003) who use a modified version of the life cycle model to study the effects of health and longevity.
} 
(2001) estimate a long run model with dynamic OLS (DOLS) for a panel of OECD countries, while Hondroyiannis (2006) analyzes a panel of European countries using the fully modified OLS (FMOLS) estimator. On the other hand, De Mello et al. (2004) and Loayza et al. (2000) use the GMM estimator developed by Arellano and Bond (1991) to better deal with endogeneity problems. However, the GMM estimator allows for a lower degree of heterogeneity with respect to the alternative models proposed above and therefore seems less appealing. Table 1 summarizes the choices made by the authors mentioned.

The authors cited above study aggregate private savings as the dependent variable and use various variables as regressors. However, only in a few cases does theory make unambiguous predictions about these variables' effects on savings. For example, demographic factors are thought to be important because of the impact of population aging: they enter the analysis as dependency ratios, but "higher proportions of the dependents to persons of working age may be associated either with higher or lower saving ratio" (Hondroyiannis, 2006, 556). On the contrary, government savings are always thought to correlate negatively with private savings, due to the effects of Ricardian equivalence (in the case of actual government borrowing, economic agents anticipate that higher taxes will be needed to pay for the borrowing, thus they immediately increase their savings). Government savings is therefore always included in the analysis, and its coefficient typically has a significant and negative impact on private savings. Several other variables are customarily included: productivity growth, changes in terms of trade, the real interest rate, inflation, and liquidity constraints. In most cases, the theoretical predictions about their influences on savings are unclear. Many of these studies fail to account for household wealth because of problems in finding data. De Serres and Pelgrin (2003) write that relevant data on the stock of wealth are available for only a few countries, while De Mello et al. (2004, 19) state that "household wealth is expected to affect consumption/saving decisions based on permanent income considerations, but data are not readily available for most countries." Since our idea is to test the importance of wealth on savings, a substantial amount of time has been spent searching for this kind of data: we aim, therefore, to fill a gap in the existing empirical literature on aggregate savings.

We comment now on the literature concerning consumption and the wealth effect. The wealth effect has been empirically tested in a number of articles using either household-level or aggregate data. ${ }^{5}$

\footnotetext{
${ }^{5}$ Consider the following examples. For the USA, Skinner (1996) finds a large and significant effect of housing wealth on consumption using aggregate data, even if in some specifications (for instance, when the long term interest rate is included in the model) the significance disappears. More recently, Belsky and Prakken (2004) find evidence in favor of the housing wealth effect, while Poterba (2000) and Juster et al. (2006) concentrate on the financial wealth effect. Turning to panel studies, Case et al. (2005) study both the financial and the housing wealth effect for a panel of 14 countries, finding a significant effect for the latter only; Edison and Slok (2002) study the financial wealth effect in 7 different countries. See Paiella (2007) for an excellent survey on the evidence of wealth effects, both from aggregate data and from micro data.
} 
For the U.S. economy, the wealth effect has been widely analyzed and several studies produced significant estimates of it, ranging between 2 and 7 cents of additional consumption per year per 1 dollar increase in household net wealth. This reflects the magnitude of the effect estimated by the Board of Governors of the Federal Reserve System, which maintains the longest and most regularly updated wealth effect estimates for the USA. In recent studies, different estimates have been produced according to the type of household wealth, dividing house equity and financial wealth (as in Case et al., 2005). Among the studies that use aggregate data, tangible wealth is either not included among the explanatory variables or included as a proxy (such as a house price index) due to problems in finding data for a large number of countries. We overcome this problem by building on an idea by Case et al. (2005), as explained in the next section.

\section{Data and empirical strategy}

\subsection{Model and data}

The methods in this paper are closer to the literature on aggregate private savings than to the literature on the wealth effect. To investigate the long run determinants of household savings, we use the following model:

$$
S a v h_{i, t}=\alpha_{i, 0}+\beta_{i, 1} W f_{i, t}+\beta_{i, 2} W t_{i, t}+\beta_{i, j} X_{i, t}+u_{i, t}
$$

where Savh is the household savings rate, $W f$ is financial wealth, $W t$ is tangible/housing wealth, and $X$ is a vector of explanatory variables taken both from the theory and from the empirical literature on savings (which varies according to the different model specifications). The variables used are described below (detailed sources can be found in the data appendix).

Aggregate household savings are divided by household disposable income to obtain the savings rate, our dependent variable. We consider income to be more appropriate than GDP as the denominator of the ratio, even if most of the literature predominantly uses the latter (a notable exception is Sarantis and Stewart, 2001). Even if countries report data on household savings differently, we feel that it is appropriate to use such a variable for international comparisons, as explained in the Notes to Statistical Annex of the OECD Economic Outlook the source of these data): "since the definition of saving is unaffected by differences in national accounts practices, this is not a source of inconsistency across countries."6

\footnotetext{
${ }^{6}$ To be precise, the differences are the following: household savings include savings of non-profit institutions serving the household sector in all the countries of the sample apart from Finland, France, Japan and New Zealand; most
} 
Net financial wealth $(W f)$ is also divided by household disposable income. Figure 3 shows the evolution of financial wealth in the countries of the sample and the effects of the 2000 stock market crisis are evident.

Tangible wealth $(W t)$ requires a deeper description. Data on tangible wealth are available only for a few countries, ${ }^{7}$ thus the construction of a proxy was necessary to use this variable for panel analysis. We begin with an idea proposed by Case et al. (2005), who built a measure of the housing market wealth for their paper about consumption and the wealth effect. ${ }^{8}$ The estimate was constructed according to the following expression:

$$
H V=H O r * H h N * P I
$$

where $H V$ is the estimated aggregate value of the houses owned by households, HOr is the home ownership rate (computed by dividing the number of owner-occupied housing units by the number of occupied housing units or households), $H h N$ is the number of households (obtained dividing the population by the household size), PI is the residential property price index (annual data produced by the BIS; detailed sources in the data appendix).

Even if equation (2) is similar to that used by Case et al. (2005), our measure is probably more accurate than theirs, since their proxy for $H h N$ is the number of persons in the population, while we used the number of households, following more closely the original idea. Moreover, we expressed the measure as an index with 2000 as the base year to have a similar magnitude for every country (after dividing $H V$ by the household disposable income). Missing data in the series of home ownership rates and household size were obtained with linear interpolation. A linear interpolation does not pose any particular problems since home ownership rates and household size both follow clear linear trends during the examined period.

According to our measure, during the period of interest household tangible/housing wealth increased in 15 countries out of 18 (see Figure 4), which is consistent with the development of household wealth as described in the majority of national studies and reports. In particular, and as highlighted by Bartiloro et al. (2007), in most countries tangible/housing wealth increased rapidly after the burst of the stock market bubble in 2000. It is important to stress that our proxy for

countries report household savings on a net basis (excluding consumption of fixed capital by households), the exceptions being Belgium, Denmark, Portugal, Spain and the United Kingdom.

${ }^{7}$ The best source of data on tangible wealth is the table "Household Wealth and Indebtedness" usually present in the Statistical Annex of the OECD Economic Outlooks. It contains data on tangible wealth for 7 OECD countries since 1980, but for most of the series the data are not harmonized. For some additional countries, data for much shorter periods of time are available from national official sources.

${ }^{8}$ This idea has been exploited by other authors too. For example, Slacalek (2006) uses similar data but claims to be able to construct a measure comparable to the financial wealth one in order to compare the magnitude of the two different wealth effects. However, we believe that in order to do this he makes certain strong assumptions that we prefer to avoid. 
tangible wealth is not directly comparable to the measure of financial wealth, which is expressed as a ratio over disposable income and has an immediate interpretation. Our measure of tangible wealth mostly reflects the movements in housing prices expressed as indexes and does not take into account the size or the quality of the houses, and in this respect is similar to the measure used by Case et al. (2005). We tested the reliability of the proxy by looking at the correlation with the direct measure of tangible wealth for the few countries for which these data are available from the OECD Economic Outlook. The high values reported in the data appendix (Table A1) verify the reliability of our proxy.

To enrich the basic model and to check for the real importance of household wealth in determining savings we used several additional variables: government savings (savg, divided by GDP), population dependency ratios ( $d r$ and $o d r$ : the former is the standard dependency ratio, while the latter takes into account the elderly part of the population only), liquidity constraints $(l c$, proxied by the ratio between private sector credit and GDP), ${ }^{9}$ inflation (infl) and the long term interest rate $(r)$. The sample includes the highest number of developed countries for which data were available, and is constituted by 18 OECD countries: Australia, Austria, Belgium, Canada, Denmark, Finland, France, Germany, Italy, Japan, the Netherlands, Norway, Portugal, Spain, Sweden, Switzerland, the United Kingdom and the United States of America. The period of analysis is 1980-2005, due to data availability. The panel is slightly unbalanced, because some countries did not have data available for the entire period of interest.

\subsection{The empirical strategy}

Due to endogeneity and cointegration issues, the estimation of the model described by equation (1) is difficult. Endogeneity arises because wealth, our main explanatory variable, is linked to the accumulation of past savings, our dependent variable. Due to the lack of appropriate instruments this problem is difficult to handle even with household-level data (Bostic et al., 2009). On cointegration, we need to avoid spurious results in the possible presence of cointegrating relationships among non-stationary variables. A number of authors exploited the existence of a cointegrating relationship by writing the model in an error correction form to handle both the shortrun and the long-run dynamics. However, we do not find the error correction form to be essential, since our interest lies in identifying the long run determinants: rebalancing actions should not address variables that influence savings in the short-run only.

\footnotetext{
${ }^{9}$ This is the usual proxy in the literature, but we feel that it poses some problems. For example, part of the credit to private sector enters the measure of net financial wealth. We would prefer to use a different, better variable, to measure liquidity constraints, but we are not aware of its existence.
} 
Despite these two issues, we begin our analysis with a few different versions of the model of Eq. (1) estimated with the fixed effects estimator (varying the variables included in the vector $X$ ). Thus we establish a benchmark against which to compare the results obtained with techniques capable of dealing with both endogeneity and cointegration. After the fixed effects estimation, we progress to a deeper analysis by investigating the existence of a cointegrating relationship among the variables of the model. Firstly, panel unit root tests are carried out to understand if the series are stationary, since cointegration can only exist among variables of the same order of integration. ${ }^{10}$ Three different tests are carried out: the ones proposed by Levin et al. (2002, LLC) and Hadri (2000), that test for the existence of a common root in the panel, and the one built by Im et al. (2003, IPS), that allows for heterogeneus, individual roots. All tests are carried out in two different model specifications: one assuming an individual intercept and the other with an individual intercept and a time trend.

Secondly, we test for the presence of cointegration among the variables, using both the Pedroni method and the Kao (1999) test. The various tests point to the presence of a cointegrating relationship among our variables of interest, thus the final step of the analysis requires that we use panel cointegration techniques to estimate our model.

Among the estimators widely used in the private savings literature, the GMM by Arellano and Bond (1991), which deals with endogeneity, and the PMG by Pesaran et al. (1999), which handles error correction forms, have been discarded because of the required dimensions of the panel. ${ }^{11}$ Two alternatives were then suitable: the DOLS proposed by Kao and Chiang (2000) in the context of panel cointegration, and the 'mean group' FMOLS proposed by Pedroni (2000). Similar to the PMG estimator, both techniques allow for a great amount of heterogeneity, but they have better properties in small samples. Finally, since the DOLS estimator requires far too great a number of leads and lags for the time dimension of our sample, our preferred estimator is the FMOLS.

The group mean panel FMOLS estimator has many useful qualities. Firstly, it has "satisfactory size and power properties even for small panels if $\mathrm{T}$ is larger than N" (Maeso-Fernandez et al., 2004, 20). Secondly, it permits a great amount of heterogeneity, even if a common, long-run relationship is estimated in addition to single country coefficients. Thirdly, it allows a flexible alternative hypothesis when estimating the average long-run cointegrating relationship:

\footnotetext{
${ }^{10}$ We choose not to perform tests at single country level, since "it is well known that the traditional unit root tests (...) method involves the low power problem for nonstationary data" (Kim et al. 2005, 75).

${ }^{11}$ However, we performed some estimations with those methods in order to have some benchmark results. The GMM results for a dynamic specification of model (2) are similar to the ones obtained with a fixed effects model, and become closer and closer as we limit the number of instruments. However, even with the minimum number of instruments possible, we cannot satisfy the requirement of having it less than or equal to the number of groups. That is, this estimator is not recommended for a panel with $\mathrm{N}=18$ and $\mathrm{T}=26$. With the PMG estimator we did not obtain clear results, probably for the same reasons.
} 
$H_{0}: \beta_{1}=0$ vs $H_{1}: \beta_{1} \neq 0$

$H_{0}: \beta_{2}=0$ vs $H_{1}: \beta_{2} \neq 0$

Since neither evidence, nor theory can suggest a possible value of the alternative hypothesis the model's flexibility is seen as advantageous. ${ }^{12}$ Lastly, this estimator takes into account the possible correlation between the error term and the differences of the regressors, and therefore makes nonparametric adjustments to the dependent variable before estimating the long run relationship.

The long run coefficient estimators can be written as follows:

$\hat{\beta}_{F M}=\left(\sum_{t=1}^{T} x_{i, t}^{\prime} x_{i, t}\right)^{-1} \sum_{t=1}^{T}\left(x_{i, t}^{\prime} y_{i, t}^{*}-T \hat{\lambda}_{i}\right)$

where $y^{*}$ are the regressands adjusted for the covariance between the error term and $T \hat{\lambda}$ is the adjustment for the presence of a constant term.

The FMOLS estimator requires that no more than one cointegrating vector among the variables of the model be present, thus we must be careful to choose explanatory variables so that we do not violate this requirement. We use the following procedure. We first estimate the model of equation (1) with the wealth variables only. We then enrich the model with variables taken from the private savings literature, adding them one at a time, to see if they are significant and if they influence the coefficient of the wealth measures. We use those results, the results from the fixed effects estimation, and the conclusions reached in the past savings literature, to estimate a final, more comprehensive model capable of grasping the real importance of wealth in determining savings in the long-run. Additional cointegration tests among the final variables are carried out to ensure that we are using the estimator properly.

\section{Estimation results}

Table 2 reports the results of the fixed effects estimation of various specifications of equation (1). Specification 1 is very parsimonious, as the two measures of wealth are the only explanatory variables. The other specifications include more regressors to check if the importance of the two measures of wealth is affected. Specifications 2 and 3 include all the variables of the dataset: the two measures of wealth, the dependency ratio (the standard one in specification 2 , the elderly ratio

\footnotetext{
${ }^{12}$ See Carroll et al. (2006) for a critical point of view on the reliability of the use of cointegration in the analysis of wealth, consumption/savings and income.
} 
in specification 3), liquidity constraints, inflation and the long term interest rate. Specifications 4 and 5 include only household wealth and the two variables that have proven to be the most important in the previous model specifications: government savings and the two dependency ratios. All the estimations are carried out both without and with time dummies added; this latter specification is indicated with 'td' after the number of the model.

Table 2 shows that the coefficients of the two measures of wealth negatively affect savings, as expected, when they appear as the only explanatory variables of the model. In this case, they account for one third of the variability of household savings. However, when other explanatory variables are added, both financial and tangible/housing wealth maintain significant coefficients only in model 5. Across all the specifications, the wealth coefficients are indeed very low, suggesting an elasticity not higher than .03. This value lies in the lower range of the estimates of the previous literature. On the contrary, the importance of government savings and of the dependency ratios seems to hold across most of the models. Their coefficients are negative and significant at conventional levels in most cases. In all models, the introduction of time dummies leads to lower coefficients for both measures of wealth, but does not affect dramatically the results.

Overall, the fixed effect estimation suggests that wealth negatively affects household savings at panel level, even if its importance diminishes, and sometimes vanishes, when other important determinants of savings are included in the model. But, we do not want to derive strong conclusions from these preliminary fixed effects estimates. Rather, we use these results to guide our analysis using panel cointegration techniques. We start with panel unit root tests.

The results of three different panel unit root tests (LLC, IPS and Hadri) for the series both in levels and in first differences are reported in Table 3. For the LLC and the IPS tests, the choice of the appropriate lag-lenghts are made according to the Schwarz-Bayesan Information Criterion.

Starting from the LLC and the IPS tests, we fail to reject the null hypothesis of nonstationarity at conventional levels for household savings, the two measures of wealth and liquidity constraints. In the case of the two dependency ratios the evidence is mixed, while the null is rejected for the other variables: inflation, long term interest rate and government savings (even if the LLC does not yield clear results). The Hadri test seems to over-reject the null hypothesis of stationarity. However, due to the results of the other tests, it can be concluded that household savings, the two measures of wealth and liquidity constraints appear to be integrated of order 1 in our dataset. The other variables seem to be stationary, even if particular attention is required to read the results for the two dependency ratios. The first dependency ratio (odr) appears to be stationary only when a time trend is not included in the specification, while for the other dependency ratio results change dramatically depending on the test. 
Among the variables that appear to be integrated of the same order, it is necessary to look for a cointegrating relationship. Firstly, we check for the existence of cointegration among the dependent variable and the two measures of wealth that are our main subject of interest and are included in every model version that we estimate. Secondly, since we need to be sure that there is only one cointegrating relationship, we also check for the existence of cointegration among the explanatory variables: if present, we cannot apply the FMOLS estimator to estimate the model described by equation (1). Results of both the Pedroni and the Kao tests are reported in Table 4 for two different specifications: with an intercept only and with an intercept and trend. Considering the Pedroni statistics in table 4, we chose to report only the two most meaningful ones according to the characteristics of our panel, that is, the non-parametric (PP) and the parametric (ADF) t-statistics. We exclude other statistics for the following reasons. Firstly, the $\mathrm{v}$ and the rho statistics are more reliable when the time dimension is at least equal to 100 , which is not the case. ${ }^{13}$ Secondly, the within-dimension weighted statistics are excluded in favor of the unweighted statistics because the unweighted statistics perform better in small samples. Thirdly, we chose to report the Kao test, even though it does not allow for heterogeneity between groups. The results from the Kao test are inconsistent with the results from the Pedroni tests, but we believe that we can ignore the Kao test results because, as mentioned, they neglect heterogeneity. Finally, we concentrate on the results of the specifications with the intercept only, since the trend is excluded in the model that we estimate. The tests seem to point towards the existence of cointegration among household savings and the two measures of wealth (the null hypothesis of no cointegration is rejected in 3 cases out of 4). On the contrary, it seems that there are no cointegrating relationships among the explanatory variables. The null hypothesis is never rejected for the case of the two measures of wealth, and it is rejected in only 1 case out of 4 when liquidity constraints and the two dependency ratios are added to the measures of wealth. This confirms that there is only one cointegrating relationship among the variables of the model when the explanatory variables are just financial wealth and tangible/housing wealth, and also when other regressors are added one at a time, as is the case in certain models considered in the next sub-section.

\subsection{The FMOLS estimation}

As a preliminary step before estimating the final specification, we estimated seven different versions of the model described by equation (1). In this first stage of the analysis, we use only three

\footnotetext{
13 "Overall, Pedroni (1997) suggests that the panel-rho statistic seems to be the most reliable when T is large enough; for small $\mathrm{T}$, the parametric group-t statistic and the panel-t statistic appear to have the highest power, followed by the panel-rho statistic" (Maeso-Fernandez et al., 2004, p. 17). Moreover, "Pedroni (1997) reports Monte Carlo simulations indicating that the panel rho and group rho have power ranging from 0 to $20 \%$ for samples with $\mathrm{T}=20, \mathrm{~N}-20$. He finds that the variance-ratio tests consistently produced low power and large size distortions" (Bonham et al., 2004, p. 16).
} 
regressors. The results of these estimations will be useful to construct the final and more comprehensive model. Only the coefficients for the whole panel are reported, even if we obtained different coefficients for each country in the sample. The right section of Table 5 shows the results for the models when time dummies are added.

The coefficients of the household wealth variables are negative and highly significant in most specifications. Concentrating on the models including time dummies, we can draw the following preliminary conclusions. In all but one case, the coefficients of the two measures of wealth are negative, as suggested by consumer theory. But, in only a few cases are the coefficients of financial wealth significant. On the contrary, tangible/housing wealth has significant and negative coefficients in every specification of the model. Also, the values of the coefficients are generally higher than the ones found with the fixed effects estimation.

Some considerations about the additional explanatory variables are also worthwhile, with one premise: for most variables, the ambiguity from a theoretical point of view is usually confirmed by mixed empirical results in the literature. To make an example, inflation is found to have a negative coefficient by Haque et al. (1999), while Hondroyiannis (2006) estimates a positive relationship with savings. Table 5 shows that the inclusion of time dummies leads to a change of sign for all the additional explanatory variables apart from liquidity constraints (whose coefficient becomes insignificant when time dummies are included). The non-significance of the coefficients of government savings, is particularly striking, since it contradicts both the results of the fixed effects estimation and the ones of the previous literature. Another difference with our preliminary estimation lies in the coefficient of the long term interest rate, which turns out to be significant. What is confirmed here is the low importance of inflation and liquidity constraints, as well as the importance of the dependency ratios.

On the basis of these results, and assessing findings from the literature on private savings, we select the variables that should be included in a correctly specified long run savings function. In addition to the two measures of wealth, we include government savings (based on the findings of the fixed effects estimation, as well as of the savings literature) and the dependency ratio. We exclude inflation, liquidity constraints (because of the predominant non-significant results found in the preliminary estimations), and the long term interest rate (since it has rarely been significant in the previous literature and our fixed effects estimation does not suggest a primary role for it).

Firstly, we must ensure that there is no cointegration among the regressors. Consequently, in Table 6 we report the results of Pedroni's PP and ADF t-statistics. As it is often the case with such tests, the results are unclear. When the intercept alone is included in the specification, the withindimension statistics fail to reject the null hypothesis of no cointegration. The opposite occurs with 
the between-dimension statistics. Thus, we proceed to estimate the final model, concentrating on several robustness checks to be sure that our conclusions are not undermined by errors in the econometric method that we chose to apply.

For the final estimation, we present the coefficients for each country in the sample together with the coefficients for the whole panel. Table 7 shows the results of the estimation with one dependency ratio only (when the other dependency ratio is used the results are qualitatively similar). Time dummies and country-specific intercepts are included.

At first glance, Table 7 confirms the existence of a negative relationship between household savings and tangible/housing wealth, since the panel coefficient is negative and highly significant. The elasticity is -0.04 , which is within the range of estimates of the previous empirical literature. A negative relationship with savings is also found for government savings and for the dependency ratio. The coefficient of financial wealth is positive, though its value is close to zero. The results seem to confirm the findings of the fixed effects estimation only partially, since in most of the specifications with fixed effects, the coefficients on both measures of wealth were not significant once other variables were included in the model. The high degree of heterogeneity across countries could play a crucial role in explaining this difference. Even though the panel coefficient of the dependency ratio is negative and significant, only 6 countries out of 18 present a similar result, suggesting that excluding one of them could lead to a change in the panel coefficient. The results for the USA are pertinent: the coefficients of the measures of wealth are both positive (even if the coefficient of tangible/housing wealth alone is significant at standard levels). This is a surprising result, since, if it is indeed robust, it would contradict substantial empirical evidence of a positive effect of increases in wealth on consumption, and thus a negative effect on savings.

To confirm whether the results are reliable we perform several robustness checks. Probably the most important check is to re-estimate the model excluding one country at a time. In such a small sample, results could change dramatically with a slight modification such as decreasing the number of countries. Consider the panel level results. In the 18 new estimates, the coefficients of the four variables do not maintain either the same sign, or the same significance, or both jointly. Such a weakness is found both for financial wealth (since the coefficient varies greatly across the 18 new estimates) and for the dependency ratio (since the coefficient changes from negative to positive in half of the new estimates). Also, the coefficient of tangible/housing wealth is positive in 3 cases, while government savings is positive only when Germany is excluded from the sample. However, half of the countries in the sample maintain significant and negative coefficients for tangible/housing wealth and government savings variables in all the new estimates, which we may read as a proof of the importance they exert on household savings. Moreover, the surprising results 
of the US case hold across all specifications, suggesting that the negative relationships for tangible/housing wealth and government savings does not hold for the US economy.

Another robustness check is the re-estimation of the model with the elderly dependency ratio in place of the other one. Though small differences appear, we reach similar conclusions. The results for tangible/housing wealth appear to hold more strongly than before and the US case presents the same surprising results. This finding appears to be the most robust. For the entire panel of developed countries, we may also speak of weak evidence favoring the existence of negative effects on household savings from tangible/housing wealth and from government savings.

We performed two additional robustness checks. In the first check, two alternative dependent variables were used to re-estimate the final model: the ratio between household savings and GDP, for which the results do not change substantially, and the ratio between private savings and GDP. With the latter, the result strengthens the coefficients of government savings, which become negative and significant for most countries, as well as at the panel level, in line with the previous literature. At the same time, and as expected, both measures of wealth lose their importance, while mixed evidence is presented for the dependency ratios.

As a last robustness check, all the models were re-estimated with a different proxy for tangible/housing wealth, with the number of households replaced by the population (following Case et al., 2005, more closely). The results do not change substantially.

\section{Conclusions}

In order to study aggregate household savings this paper merges two strands of literature. Because it establishes a long-run relationship between savings and several explanatory variables, the model is embedded in a larger literature relating to aggregate private savings. Since the main idea was to test the relevance of the literature on consumption and the wealth effect, the main regressors were two measures of household wealth (financial wealth and tangible/housing wealth). A great effort was devoted to collecting net financial wealth data and the data that were used to build the proxy for tangible wealth. To test their importance in a comprehensive model, the preferred specification contained a variable for government savings, which has often explained private savings in the previous literature, and a dependency ratio.

Using an econometric framework that allows great heterogeneity, this paper finds evidence that tangible/housing wealth in developed countries negatively affected household savings in the period 1980-2005. The estimated elasticity (-0.04) is consistent with the literature on the wealth effect. This is true even when government savings and other variables from the literature on private savings enter the model. A similar effect for financial wealth does not seem evident. The results 
provide partial support for the authors currently blaming the housing market boom for the decline in household savings ratios. However, since the decline is a longer period phenomenon, it only constitutes a part of the underlying story. For the period under consideration, household tangible/housing wealth increased for most of the countries in the sample for many reasons additional to the behavior of prices. For instance, the developments of home ownership rates should be taken into account when speaking about household wealth. Lastly, the US results with the final model show a positive coefficient for tangible/housing wealth, providing evidence against the existence of an aggregate wealth effect in the US. This is particularly striking, since for the US there is substantial empirical evidence supporting a significant negative wealth effect on savings. In our model we control for the possible effects of national peculiarities, since we included countryspecific dummies in the final specification. The lack of a universal health care system in the US is therefore appropriately taken into account and should not be thought of driving our results.

Our analysis suggests that when other explanatory variables enter the analysis, the negative effects of wealth increases on household savings disappear. This is in line with other studies that present doubts about the channels by which the wealth effect operates (Poterba, 2000, and McCarthy and Steindel, 2006). Consider the following explanation. While rising property prices may exert a negative influence on savings for home owners, they could exert the opposite effect on households planning to buy houses because they would be forced to save more to buy more expensive houses. Both effects can be captured by our tangible/housing wealth variable, since it reflects movements of property prices, as explained in Section 3. Our analysis suggests that the positive wealth effect of households intending to buy offsets the negative effect enjoyed by home owners. This suggests that policy authorities that are willing to act to increase savings should not wait for housing prices to decrease to see an increase in household and private savings. Instead, they should take actions to correct savings independently of the movements of housing prices. Consequently, the causes of the decline in aggregate household savings must relate to something else. For example, Blanchard (2007) suggests that, in addition to public dissaving, incorrect expectations about retirement benefits and health care could be at the root of the US household behavior. Both are variables that can be influenced by the fiscal authorities, for example via information campaigns.

To conclude, since the importance of other variables related to the life-cycle model could be tested, additional work is definitely required. Finally, it would be interesting to perform a detailed analysis of household savings for the US case, still using variables both from the wealth effect theory and from the private savings literature. Expanding the analysis using data at the household or individual level seems to be the natural extension of the present work to study additional features that cannot be grasped with aggregate data. For example, age-related considerations and the effects that the 
distribution of wealth among households could present are better analyzed with micro data and several authors suggest that it could play an important role in determining the wealth effect. 


\section{Data Appendix}

Household savings (Savh). The variable is constructed by dividing SAVH (household saving) by GDP (gross domestic product). The source for both series is the OECD Economic Outlook No. 81, June 2007.

Household financial wealth (Wf). The variable is constructed by dividing the Net financial wealth (assets - liabilities) by household disposable income (YDH, taken from the OECD Economic Outlook No. 81, June 2007). The sources for financial assets and liabilities are the following: Australia: "Australian National Accounts: Financial Accounts" (5232.0), Australian Bureau of Statistics, Canberra. Austria: OeNB. Belgium: Nationale Bank van België (many thanks to Ms Viviane de Pré). Canada: Riccardo de Bonis, Daniele Fano and Teresa Sbano provided me the data for this and 7 other countries (from now onwards I will refer to this source as dBFS). The data on assets are described in de Bonis, Fano and Sbano (2007). I am really grateful to them for this great help. Denmark: Eurostat Financial Accounts. Finland: Eurostat Financial Accounts. France: dBFS. Germany: dBFS. Italy: dBFS. Japan: dBFS. Netherlands: Eurostat Financial Accounts. Norway: Statistisk Sentralbyrå (many thanks to Mr Torbjørn Rønning). Portugal: estimates produced by Cardoso and Geraldes da Cuhna (2005). Spain: dBFS. Sweden: Statistiska Centralbyrån (many thanks to Mr Michael Wolf and Ms Maria Andersson). Switzerland: Schweizerische Nationalbank. United Kingdom: dBFS. United States of America: dBFS.

Household tangible/housing wealth $(\mathrm{Wt})$. The variable is constructed as described in Section 3 . The index has been built thanks to 3 separate variables, each one of them was taken from a number of different sources (the exception being Portugal, since we used the estimation by Cardoso and Geraldes da Cuhna (2005), since data on house prices have proven difficult to be found).

Home ownership rates have been collected from several different national sources. As we realized during the data collection period, there does not exist a unique source for this kind of data for groups of countries. Data on recent years have been published by the United Nations in the "UN Bulletin of Housing Statistics for Europe and North America" (2006). One of the few attempts to merge information to build a rich dataset is Atterhög (2005). This article proved useful especially for the list of national sources for 13 developed countries, even if the data that we collected sometimes differ from the ones reported there. The additional sources that we used are the following: Australia: Australian Bureau of Statistics. Austria: Statistics Austria (many thanks to Ms Johanna Janecek). Belgium: Belgian Census and Population Registers. Canada: Source: Canada Mortgage and Housing Corporation, adapted from Statistics Canada (Census of Canada). Denmark: Statistics Denmark. Finland: Tilastoteskus (many thanks to Mr Petri Kettunen). France: Institut 
National de la Statistique et des Études Économiques. Germany: Atterhög (2005) and United Nations. Italy: Istat (many thanks to Mr Armando Dionisi). Japan: Japan Bureau of Statistics (many thanks to Mr Masao Matsumoto). Netherlands: Atterhog (2005). Norway: Statistisk Sentralbyrå. Spain: Atterhög (2005) and Household Continuous Budget Survey. Sweden: Statistiska Centralbyrån (many thanks to Ms Karin Rosén Karlsson). Switzerland: Swiss Federal Statistical Office. United Kingdom: Statistics U.K. United States of America: U.S. Census Bureau.

Figure A1 illustrates the data that we collected. As far as we know, this dataset is one of the few existing comprehensive datasets on home ownership rates.

The number of households for each country has been calculated by dividing the population (source: World Development Indicators, World Bank) by the household size. For the latter type of data, the article "Indicator Fact Sheet Signals" published by the European Environment Agency (EEA (2001)) has proven useful. Data about the number of households there "are generally based on data collection by national surveys". Data about the latest year of the period of interest have been collected from various other national sources (in some cases data for the whole period have been taken from one of the following national sources): Australia: Australian Government, Department of Family and Community Services. Austria: Statistics Austria. Belgium: 1991, Recensement de la population et des logements de la Direction générale Statistique et Information économique (situation au 1 mars); à partir de 1998, Registre national (situation au 1 janvier) - calculs Direction générale Statistique et Information économique. Canada: Canada's Office of Consumer Affairs (OCA), Consumer Report. Denmark: Statistics Denmark. Finland: Tilastoteskus. France: recensements 1975 à 1990, estimations à partir du recensement 1999, de Sitadel et de l'enquête annuelle de recensement 2005, INSEE et SESP. Germany: Statistiches Bundesamt Deutschland. Italy: Istat. Japan: Japan Bureau of Statistics. Netherlands: Statistics Netherlands. Norway: Statistisk Sentralbyrå. Spain: Census (1991 and 2001), Aceprensa (1981), Spanish Propery News (2006). Sweden: Statistiska Centralbyrån. Switzerland: Census and Global Dem.com. United Kingdom: Communities and Local Government. United States of America: U.S. Census Bureau, Current Population Survey. Figure A2 illustrates the data that we collected. We believe that they show an interesting (although well known) trend for developed countries.

The house price index for all the countries in the sample comes from the Bank for International Settlements (many thanks to Mr Markus Kramer). Here is the detailed source: Residential property prices.csv: "National sources" as per detailed documentation; Residential property prices IT.xls Nomisma; http://www.reinet.or.jp/e/jreidata/a_shi/index.htm: source for Japanese residential property prices; Annual residential property prices.xls: "BIS calculations based on national data". 
We believe that our measure of tangible/housing wealth is very accurate. Tangible wealth data are available only for some countries in the OECD Economic Outlook, and the following table presents the correlation between the OECD data and our measure. Data for Sweden were kindly provided by Mr Michael Wolf, of Statistics Sweden. The correlation is very close to 1 and it is always statistically significant for all countries apart from Germany.

Government savings (Savg). The variable is constructed by dividing SAVG (government saving) by GDP (gross domestic product). The source for both series is the OECD Economic Outlook No. 81, June 2007.

Dependency ratio (dr). The dependency ratio is the ratio of dependents (people younger than 15 and older than 64) to the working-age population (those ages 15-64). The source is the World Bank, World Development Indicators.

Elderly dependency ratio (odr). The difference with the previous dependency ratio lies in the numerator, because only the fraction of population older than 64 is divided by the working age population.

Inflation (infl). Inflation has been calculated as the yearly variation of the Consumer Price Index, taken from the OECD Economic Outlook No. 81, June 2007.

Long term interest rate (r). This is the long-term interest rate on government bonds, taken from the OECD Economic Outlook No. 81, June 2007.

Liquidity constraints (lc). This variable is constructed as the ratio between credit to private sector (source: International Monetary Fund, International Financial Statistics) and GDP (taken again from the OECD Economic Outlook No. 81, June 2007). 


\section{References}

Ando, A. \& Modigliani, F. (1963). The "Life Cycle" Hypothesis of Saving: Aggregate Implications and Tests. The American Economic Review, Vol. 53, No. 1, pp. 55-84, March.

Arellano, M. \& Bond, S. (1991). Some Tests of Specification for Panel Data: Monte Carlo Evidence and an Application to Employment Equations. Review of Economic Studies Vol. 58(2), pp 277-97, April.

Bartiloro, L., Coletta, M. \& De Bonis, R. (2007). Italian Household Wealth in a Cross Country Perspective. Bank of Italy conference: Household Wealth in Italy, Perugia.

Bernanke, B. (2005). The Global Saving Glut and the U.S. Current Account Deficit, Remarks at the Sandridge Lecture. Virginia Association of Economics, Richmond, Virginia, Federal Reserve Board, March.

Bertola, G. \& Hochguertel, S. (2007). Household debt and credit: Economic Issues and Data Problems. Economic Notes, 36(2):115-146.

Blanchard, O. (2007). Current Account Deficits in Rich Countries. NBER Working Paper 12925, February.

Bloom, D., Canning, D. \& Graham, B. (2003). Longevity and Life-cycle Savings. Scandinavian Journal of Economics, 105(3), 319-338.

Bonham, C. \& Gangnes, B. (2007). Fragmentation and East Asia Information Technology Trade. Applied Economics Vol. 39, No. 2, pp. 215-228.

Bostic, R., Gabriel, S. \& Painter, G. (2009). Housing Wealth, Financial Wealth, and Consumption: New Evidence from Micro Data. Regional Science and Urban Economics, Vol. 39, 79-89.

Cardoso, F. \& Geraldes da Cuhna, V. (2005). Household Wealth in Portugal: 1980-2004. Banco de Portugal Economic Bulletin, Autumn. 
Carroll, C., Otsuka, M. \& Slacalek, J. (2006). How Large Is the Houseing Wealth Effect? A New Approach. NBER Working Paper 12476.

Case, K., Quigley, J. \& Shiller, R. (2005). Comparing Wealth Effects: the Stock Market versus the Housing Market. Advances in Macroeconomics Vol. 5, Issue 1.

Chandrasekhar, C. P. \& Ghosh, J. (2005). The Myth of A Global Savings Glut. networkideas.org.

De Mello, L., Kongsrud, P. \& Price, R. (2004). Saving Behaviour and the Effectiveness of Fiscal Policy. OECD Economics Department Working Papers No. 397.

De Serres, A. \& Pelgrin, F. (2003). The Decline in Private Saving Rates in the 1990s in OECD Countries: How Much Can Be Explained by Non-Wealth Determinants?. OECD Economic Studies No. 36 .

Dooley, M., Folkerts-Landau, D. \& Garber, P. (2005). International Financial Stability: Asia, Interest Rates, and the Dollar. Deutsche Bank Global Research.

Edison, H. \& Sløk, T. (2002). Stock Market Wealth Effects and the New Economy: a Cross-country Study. International Finance 5:1, pp. 1-22.

Edwards, S. (1995). Why Are Saving Rates so Different Across Countries?: an International Comparative Analysis. NBER working paper No. 5097.

EA. (2001). Household number and size, in "Indicator Fact Sheet Signals 2001," European Environment Agency.

Eichengreen, B. (2006). Should There Be a Coordinated Response to the Problem of Global Imbalances? Can There Be One?. University of California, Berkeley.

Faulkner-MacDonagh, C. (2003). U.S. Household Saving: Long-Run Determinants and Short-Term Risks, in United States: Selected Issues, IMF Staff Country Report No. 03/245, Washington, International Monetary Fund. 
Feldstein, M. (2008). Resolving the Global Imbalance: The dollar and the US Saving Rate. NBER Working Paper, No. 13952.

Ferrucci, G. \& Miralles, C. (2007). Saving Behaviour and Global Imbalances - the Role of Emerging Market Economies. ECB Working Paper Series No. 842.

Gray, P. (2004). The Exhaustion of the Dollar. London and New York: Palgrave Macmillan.

Hadri, K. (2000). Testing for Stationarity in Heterogeneous Panel Data. The Econometrics Journal Vol. 3, Issue 2, pp. 148-161.

Haque, N., Pesaran, H. \& Sharma, S. (1999). Neglected Heterogeneity and Dynamics in Crosscountry Savings Regressions. IMF Working Paper 99/128.

Heer, B. and Suessmuth, B. (2006). The Savings-Inflation Puzzle. CESifo Working Paper, No. 1645 .

Hondroyiannis, G. (2006). Private Saving Determinants in European Countries: a Panel Cointegration Approach. The Social Science Journal No. 43, pp. 553-569.

Im, K. S., Pesaran, H. \& Shin, Y. (2003). Testing for Unit Roots in Heterogeneus Panels. Journal of Econometrics, 115(1):53-74.

Jappelli, T. \& Pagano, M. (1994). Saving, Growth, and Liquidity Constraints. Quarterly Journal of Economics No. 109(1), pp. 83-109.

Juster, F. T., Lupton, J., Smith, J. \& Stafford, F. (2006). The Decline in Household Saving and the Wealth Effect. The Review of Economics and Statistics, Vol. 88, No. 1, pp. 20-27.

Kao, C. (1999). Spurious Regression and Residual-based tests for Cointegration in Panel Data. Journal of Econometrics Vol. 90, Issue 1, pp. 1-44.

Kao, C. \& Chiang M. (2001). On the Estimation and Inference of a Cointegrated Regression in Panel Data. Advances in Econometrics No. 15, pp. 179-222. 
Kim, H., Oh, K. \& Jeong, C. (2005). Panel Cointegration Results on International Capital Mobility in Asian Economies. Journal of International Money and Finance No. 24, pp. 71-82.

Levin, A., .Lin, C. \& Chu, C. (2002). Unit Root Tests in Panel Data: Asymptotic and Finite-sample Properties. Journal of Econometrics Vol. 108, Issue 1, pp. 1-24.

Loayza, N., Schmidt-Hebbel, K. \& Servèn, L. (2000). What Drives Private Saving Across the World?. The Review of Economics and Statistics Vol. 82 No. 2.

Maeso-Fernandez, F., Osbat, C. \& Schnatz, B. (2004). Towards the Estimation of Equilibrium Exchange Rates for CEE Acceding Countries: Methodological Issues and a Panel Cointegration Perspective. ECB Working Paper Series No. 353.

McCarthy, J. \& Steindel, C. (2006). Housing Activity, Home Values and Consumer Spending. Proceedings, pp. 78-89.

Paiella, M. (2007). The Stock Market, Housing and Consumer Spending: a Survey of the Evidence on Wealth Effect. Bank of Italy conference: Household Wealth in Italy, Perugia.

Pedroni, P. (2000). Fully Modified OLS for Heterogeneus Cointegrated Panels. Advances in Econometrics, Vol. 15, pp. 93-130, Elsevier Science Inc.

Pesaran, H., Shin, Y. \& Smith, R. (1999). Pooled Mean Group Estimation of Dynamic Heterogeneus Panels. Journal of the American Statistical Association No. 94, pp. 621-634.

Poterba, J. (2000). Stock Market Wealth and Consumption. The Journal of Economic Perspectives Vol. 14, No. 2.

Roubini, N. \& Setser, B. (2004). The US as A Net Debtor: The Sustainability of the US External Imbalances. NYU.

Sarantis, N. and Stewart, C. (2001). Saving Behaviour in OECD Countries: Evidence from Panel Cointegration Tests. The Manchester School No. 69(s1), pp. 22-41. 
Skinner, J.S. (1996). Is Housing Wealth a Sideshow? Advances in the Economics of Aging, 1996.

Slacalek, J. (2006). What Drives Personal Consumption? The Role of Housing and Financial Wealth. Discussion Papers of DIW Berlin.

Summers, L. (2003). The United States and the Global Adjustment Process. Speech at the Third Annual Stavros S. Niarchos Lecture, Institute of International Economics.

Terrones, M. \& Cardarelli, R. (2005). Global Imbalances: A Saving and Investment Perspective, in IMF World Economic Outlook.

Truman, E. (2004). Budget and External Deficits: Not Twins but the Same Family, in: Kopcke, R., G. Tootell and R. Triest eds., The Macroeconomics of Fiscal Policy, Cambridge and London: MIT Press. 


\section{Figures and Tables}

Figure 1. Declining private saving rates in some developed countries

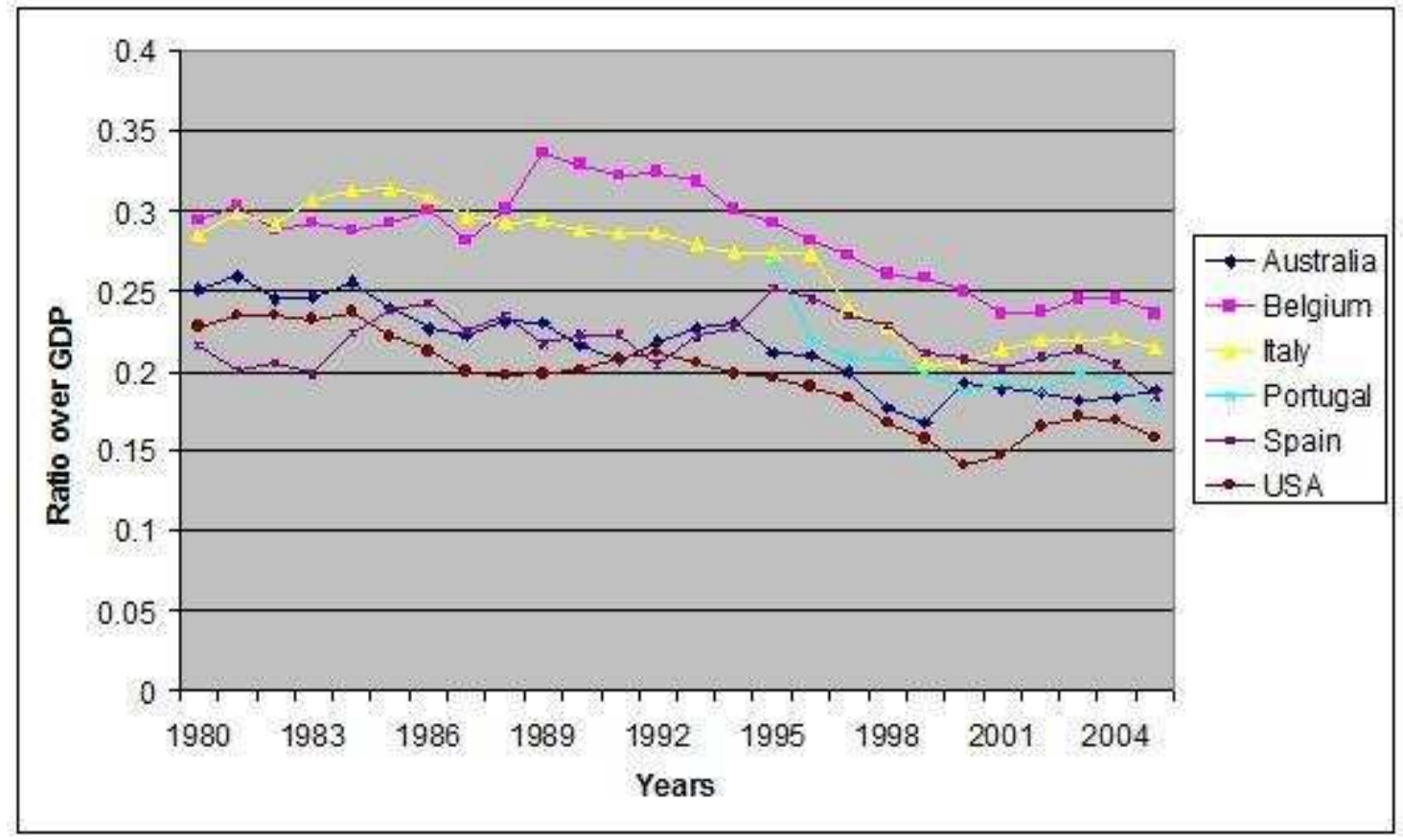

Figure 2. Declining household saving rates in developed countries

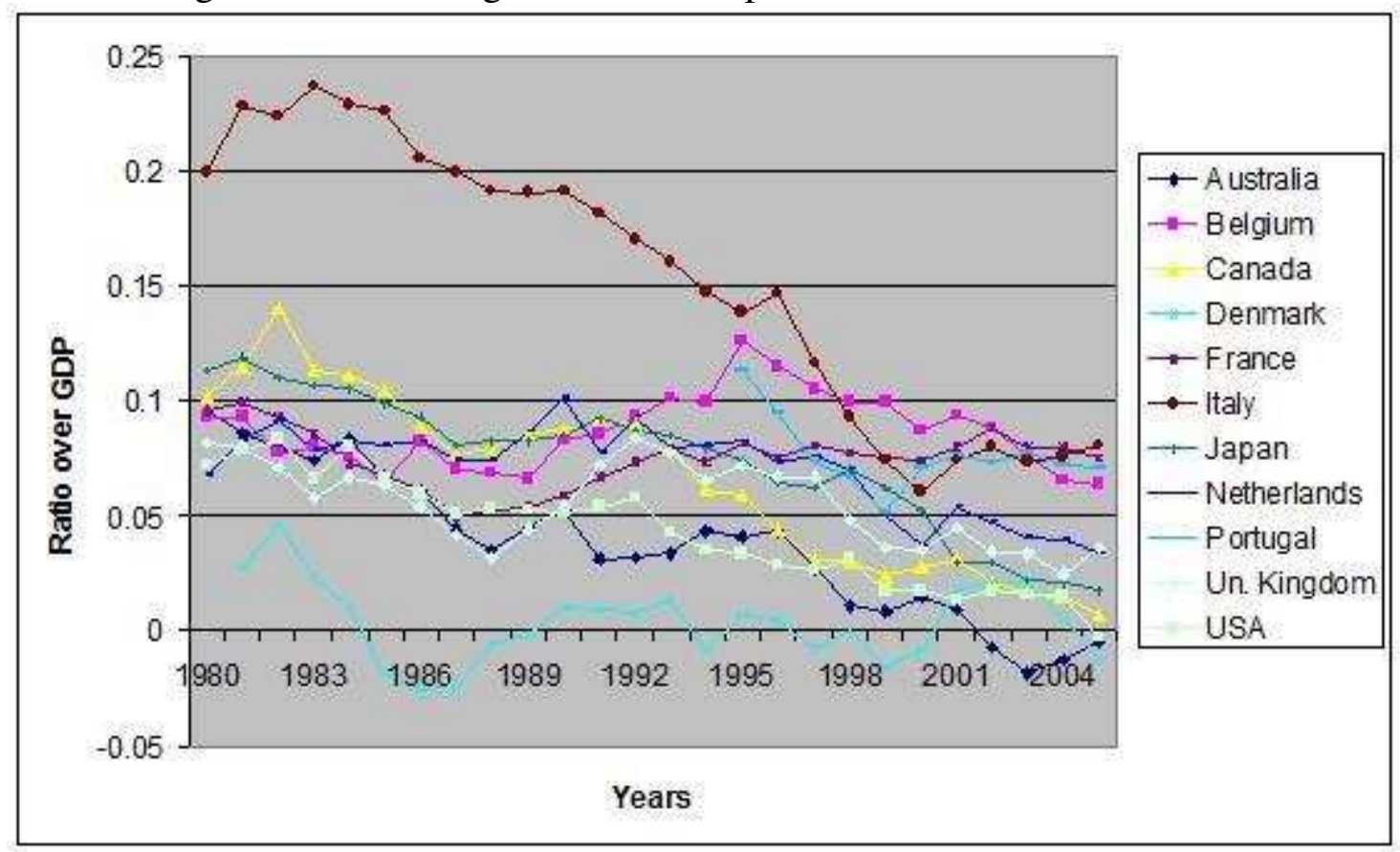


Figure 3. Financial wealth in developed countries

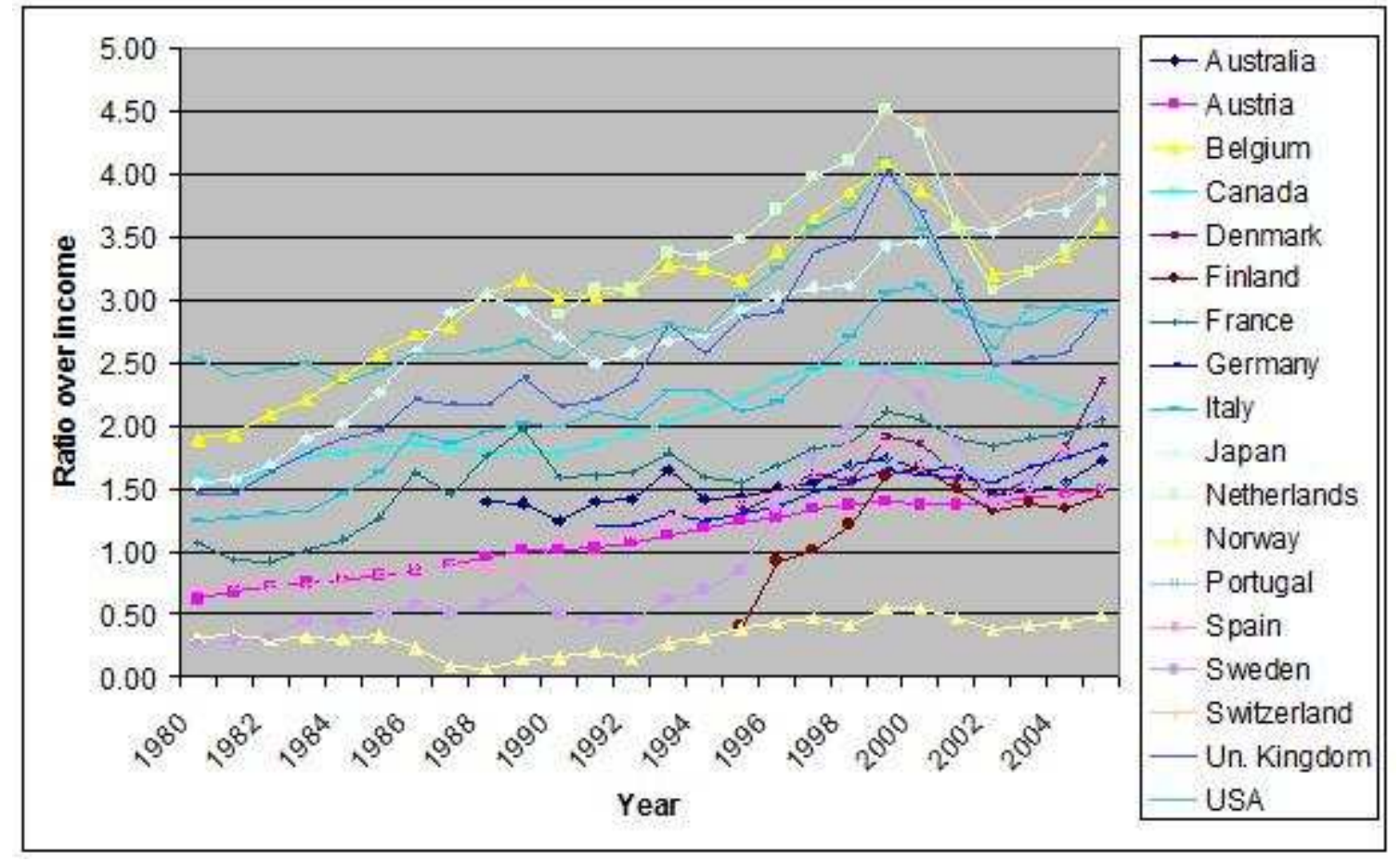

Figure 4. Tangible/housing wealth in developed countries

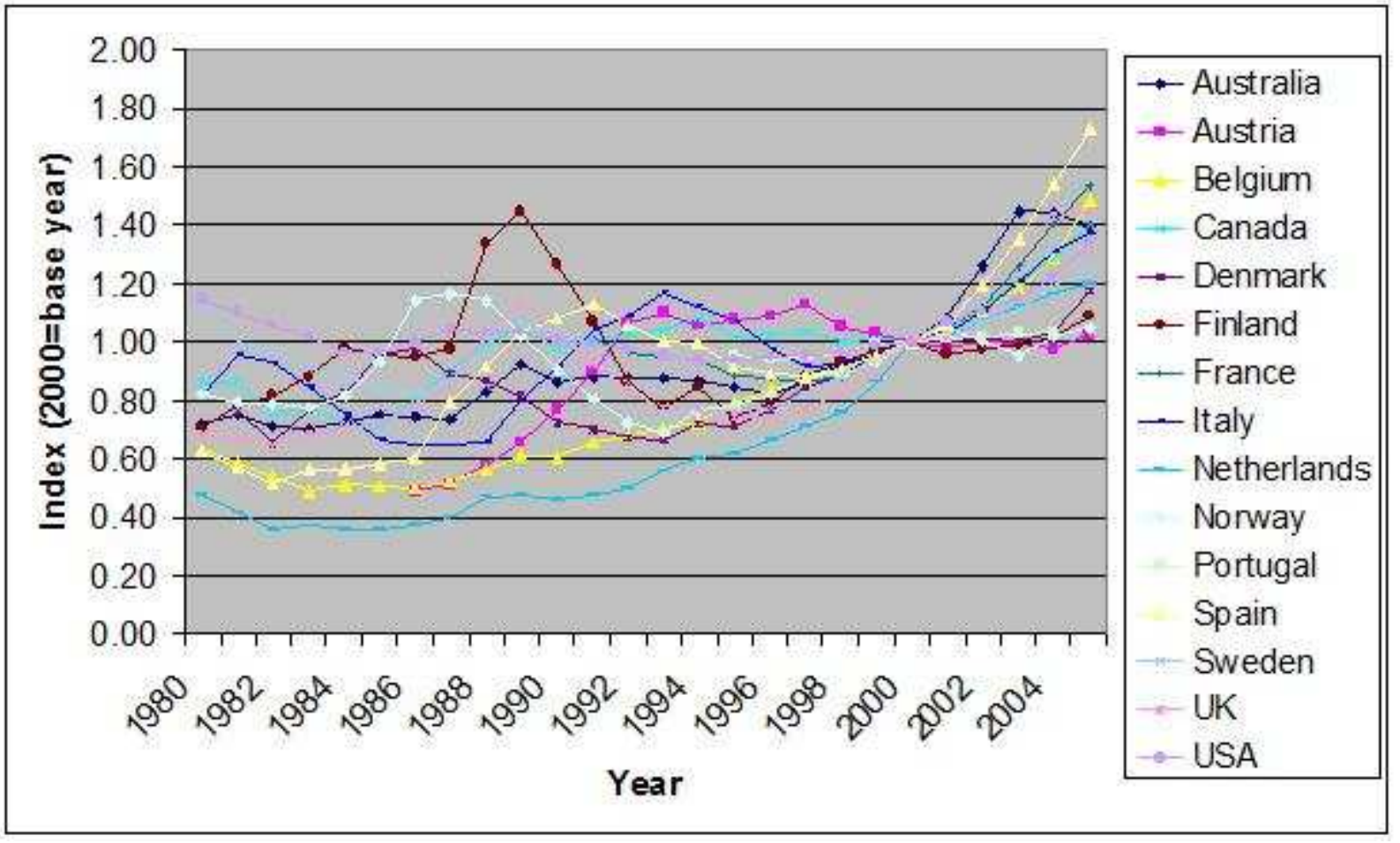


Figure A1. Home ownership rates in developed countries

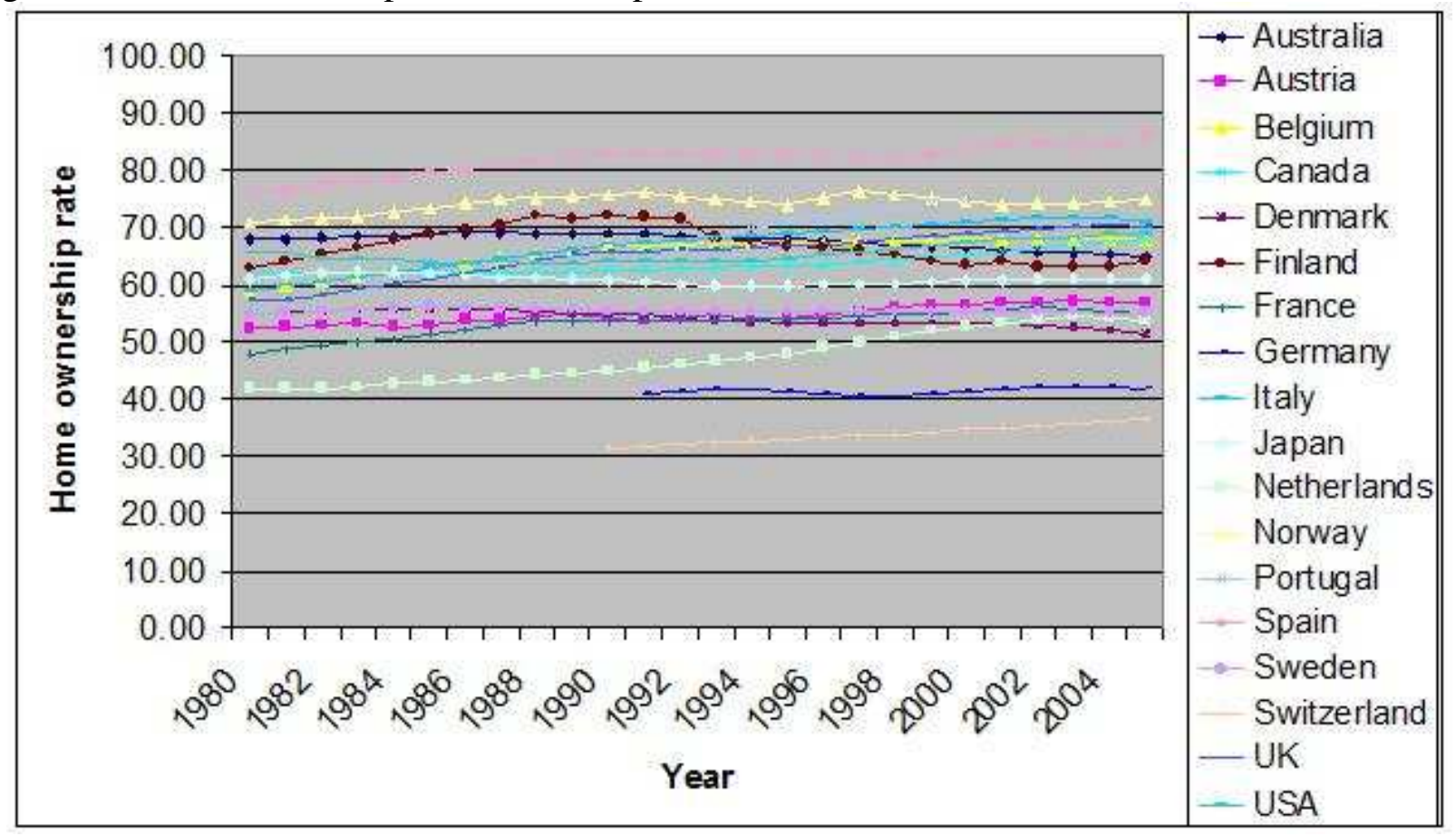

Figure A2. Household sizes in developed countries

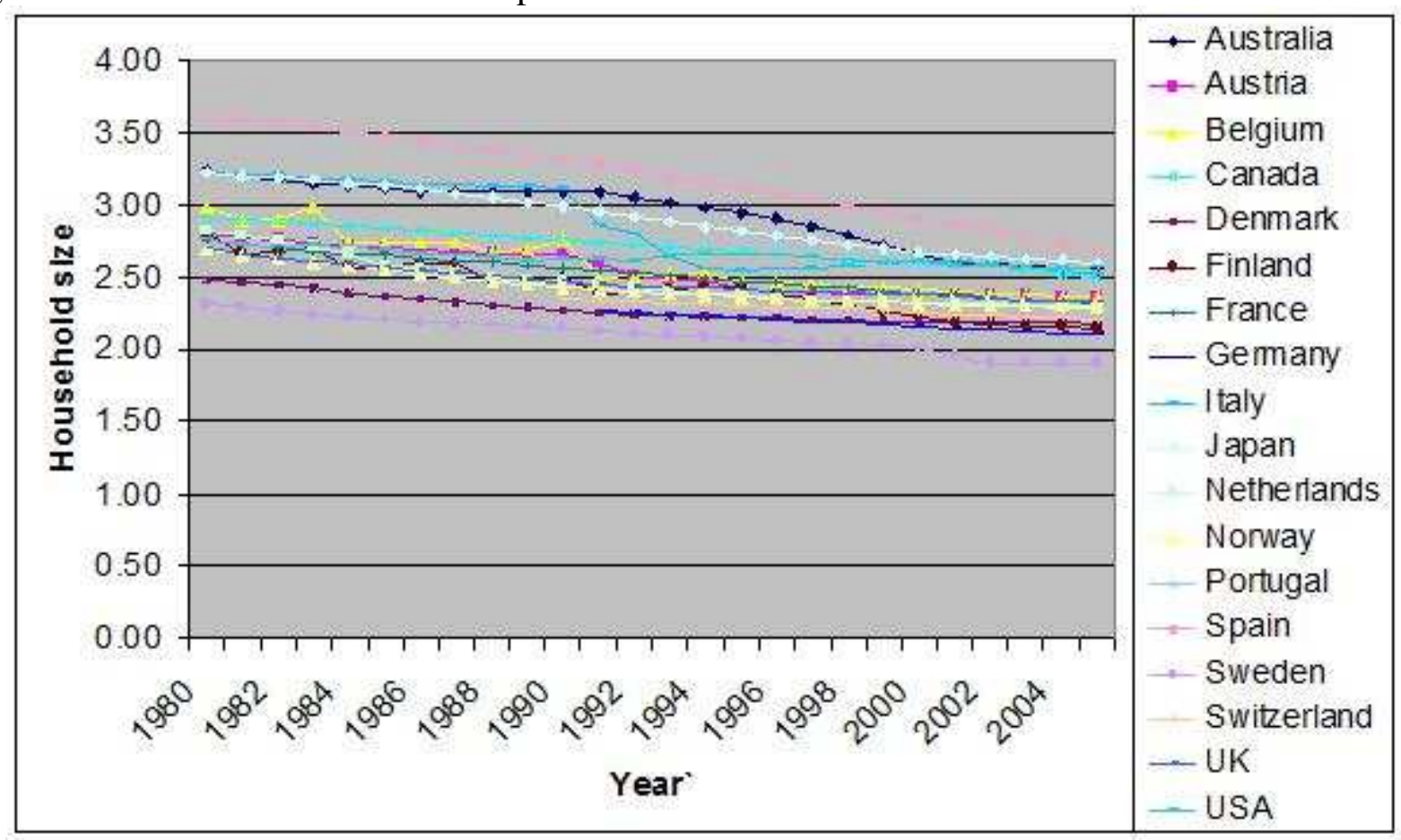


Table 1. Existing literature: examined panels and econometric choices

\begin{tabular}{|l|c|c|c|}
\hline Article & N. of countries & N. of years & Estimation technique \\
\hline Edwards 1995 & 36 & 23 & IV \\
Loayza et al. 2000 & 69 & variable & GMM \\
Bloom et al. 2003 & 68 & 20 & FE \\
Haque et al. 1999 & 21 & 23 & PMG \\
De Mello et al. 2004 & 21 & 33 & GMM \\
De Serres et al. 2003 & 15 & 31 & PMG \\
Ferrucci et al. 2007 & 48 & 26 & PMG \\
Sarantis et al. 2001 & 20 & 40 & DOLS \\
Hondroyiannis 2006 & 13 & 38 & FMOLS \\
\hline
\end{tabular}

Table 2. Fixed Effects estimation results, 5 different models

\begin{tabular}{|c|c|c|c|c|c|c|c|c|c|c|}
\hline & 1 & $1 \mathrm{td}$ & 2 & $2 \mathrm{td}$ & 3 & $3 t d$ & 4 & $4 \mathrm{td}$ & 5 & $5 t d$ \\
\hline \multirow[t]{2}{*}{ Wf } & $-0.02^{\star * *}$ & $-0.01^{\star *}$ & 0.00 & 0.00 & 0.01 & 0.00 & 0.00 & 0.00 & $-0.02^{\star * *}$ & $-0.01^{*}$ \\
\hline & $(-7.84)$ & $(-2.30)$ & $(-0.84)$ & $(-0.89)$ & -1.63 & -0.95 & $(-0.12)$ & -0.20 & $(-7.29)$ & $(-1.79)$ \\
\hline \multirow[t]{2}{*}{ Wt } & $-0.03^{\star * *}$ & $-0.02^{*}$ & $-0.01^{*}$ & -0.01 & 0.00 & 0.00 & 0.00 & -0.01 & $-0.03^{\star * *}$ & $-0.02^{*}$ \\
\hline & $(-4.54)$ & $(-1.89)$ & $(-1.66)$ & $(-1.40)$ & $(0.60)$ & $(-0.15)$ & $(-0.27)$ & $(-0.81)$ & $(-3.63)$ & $(-1.77)$ \\
\hline \multirow[t]{2}{*}{ savg } & & & $-0.17^{* * *}$ & $-0.12^{\star *}$ & $-0.32^{* * *}$ & $-0.27^{* * *}$ & $-0.27^{* * *}$ & $-0.23^{\star * *}$ & $-0.11^{* *}$ & -0.08 \\
\hline & & & $(-3.54)$ & $(-2.05)$ & $(-6.77)$ & $(-5.09)$ & $(-5.92)$ & $(-4.56)$ & $(-2.30)$ & $(-1.40)$ \\
\hline \multirow[t]{2}{*}{$\mathrm{dr}$} & & & $-0.20^{\star * *}$ & $-0.24^{\star * *}$ & & & & & $-0.11^{*}$ & $-0.20^{* * *}$ \\
\hline & & & $(-2.83)$ & $(-3.15)$ & & & & & $(-1.65)$ & $(-2.80)$ \\
\hline \multirow[t]{2}{*}{ odr } & & & & & $-0.67^{\star \star *}$ & $-0.77^{\star * *}$ & $-0.69^{* * *}$ & $-0.75^{\star * *}$ & & \\
\hline & & & & & $(-9.41)$ & $(-10.03)$ & $(-10.17)$ & $(-10.26)$ & & \\
\hline \multirow[t]{2}{*}{ IC } & & & 0.00 & 0.00 & -0.01 & $-0.01^{*}$ & & & & \\
\hline & & & $(-0.19)$ & -0.43 & $(-1.16)$ & $(-1.92)$ & & & & \\
\hline \multirow[t]{2}{*}{ infl } & & & 0.00 & 0.00 & $0.00^{* *}$ & $0.00^{*}$ & & & & \\
\hline & & & (1.54) & (0.39) & (2.35) & $(1.76)$ & & & & \\
\hline \multirow[t]{2}{*}{ r } & & & $0.00^{* \star *}$ & $0.00^{* *}$ & 0.00 & 0.00 & & & & \\
\hline & & & $(2.66)$ & (2.02) & $(-0.27)$ & $(0.43)$ & & & & \\
\hline$R^{\wedge} 2$ & 0.26 & 0.33 & 0.33 & 0.38 & 0.46 & 0.51 & 0.44 & 0.50 & 0.27 & 0.35 \\
\hline No. of obs. & 368 & 368 & 365 & 365 & 365 & 365 & 368 & 368 & 368 & 368 \\
\hline
\end{tabular}

t-values are in parenthesis; * ${ }^{* *},{ }^{* * *}$ significant at 10,5 and $1 \%$ respectively. 
Table 3. Panel unit root tests results, p-values

\begin{tabular}{|c|c|c|c|c|c|c|}
\hline \multirow[t]{2}{*}{ Variables } & \multicolumn{2}{|c|}{ LLC } & \multicolumn{2}{|c|}{ IPS } & \multicolumn{2}{|c|}{ Hadri } \\
\hline & $\begin{array}{l}\text { Individual } \\
\text { intercept }\end{array}$ & $\begin{array}{l}\text { Ind. interc. } \\
\text { and trend }\end{array}$ & $\begin{array}{l}\text { Individual } \\
\text { intercept }\end{array}$ & $\begin{array}{l}\text { Ind. interc. } \\
\text { and trend }\end{array}$ & $\begin{array}{l}\text { Individual } \\
\text { intercept }\end{array}$ & $\begin{array}{l}\text { Ind. interc. } \\
\text { and trend }\end{array}$ \\
\hline Savh & 0.54 & 0.19 & 0.55 & 0.01 & 0.00 & 0.00 \\
\hline $\mathrm{D}$ (savh) & 0.00 & 0.00 & 0.00 & 0.00 & 0.84 & 0.08 \\
\hline Wf & 0.01 & 0.21 & 0.37 & 0.16 & 0.00 & 0.00 \\
\hline$D(w f)$ & 0.00 & 0.00 & 0.00 & 0.00 & 0.48 & 0.00 \\
\hline Wt & 1.00 & 0.89 & 1.00 & 0.69 & 0.00 & 0.00 \\
\hline$D(w t)$ & 0.01 & 0.01 & 0.00 & 0.00 & 0.00 & 0.00 \\
\hline Savg & 0.13 & 0.08 & 0.03 & 0.01 & 0.00 & 0.00 \\
\hline $\mathrm{D}$ (savg) & 0.00 & 0.00 & 0.00 & 0.00 & 0.73 & 0.14 \\
\hline odr & 0.52 & 0.00 & 0.96 & 0.00 & 0.00 & 0.00 \\
\hline $\mathrm{D}$ (odr) & 0.01 & 1.00 & 0.00 & 0.44 & 0.00 & 0.00 \\
\hline $\mathrm{dr}$ & 0.59 & 1.00 & 0.00 & 0.00 & 0.00 & 0.00 \\
\hline$D(d r)$ & 0.00 & 0.02 & 0.00 & 0.00 & 0.00 & 0.00 \\
\hline infl & 0.00 & 0.00 & 0.00 & 0.00 & 0.00 & 0.00 \\
\hline$D$ (infl) & 0.00 & 0.00 & 0.00 & 0.00 & 0.00 & 0.00 \\
\hline$r$ & 0.01 & 0.00 & 0.90 & 0.00 & 0.00 & 0.00 \\
\hline$D(r)$ & 0.00 & 0.00 & 0.00 & 0.00 & 0.52 & 0.00 \\
\hline IC & 1.00 & 0.41 & 1.00 & 0.77 & 0.00 & 0.00 \\
\hline $\mathrm{D}(\mathrm{Ic})$ & 0.00 & 0.00 & 0.00 & 0.00 & 0.00 & 0.00 \\
\hline
\end{tabular}

$\sim$ Null hypothesis here is No Unit root, differently from the other tests. The p-values of the tests are reported in the table for both the series and their first differences; the test statistics follow an asymptotic normal distribution (correcting for the dimensions of the panel does not affect the results). 
Table 4. Panel cointegration tests

\begin{tabular}{|c|c|c|c|c|c|}
\hline & \multirow[b]{2}{*}{$\begin{array}{c}\text { Model } \\
\text { Specification }\end{array}$} & \multicolumn{2}{|c|}{ Within dimension } & \multicolumn{2}{|c|}{ Between dimension } \\
\hline & & $\begin{array}{l}\text { Intercept, } \\
\text { no trend }\end{array}$ & $\begin{array}{l}\text { Intercept } \\
\text { and trend }\end{array}$ & $\begin{array}{l}\text { Intercept, } \\
\text { no trend }\end{array}$ & $\begin{array}{l}\text { Intercept } \\
\text { and trend }\end{array}$ \\
\hline Variables & Statistics & & & & \\
\hline \multirow[t]{3}{*}{ Savh, Wf } & PP & -0.401 & $-1.980^{\star \star}$ & 0.85 & $-3.531^{* * *}$ \\
\hline & ADF & -1.255 & $-3.060^{\star * \star}$ & -0.001 & $-3.916^{\star * *}$ \\
\hline & Kao (ADF) & 0.568 & & & \\
\hline \multirow[t]{3}{*}{ Savh, Wt } & PP & -0.946 & -1.561 & -0.321 & -1.493 \\
\hline & ADF & $-2.118^{\star \star}$ & $-2.146^{\star *}$ & -1.294 & $-3.009^{\star \star \star}$ \\
\hline & Kao (ADF) & -1.068 & & & \\
\hline \multirow[t]{3}{*}{ Savh, Wf, Wt } & PP & -1.02 & -1.071 & $-2.892^{* * *}$ & $-4.572^{\star * *}$ \\
\hline & ADF & $-2.411^{\star *}$ & -1.064 & $-3.852^{\star * \star}$ & $-3.697^{* * *}$ \\
\hline & Kao (ADF) & 0.521 & & & \\
\hline \multirow[t]{3}{*}{ Wt, Wf } & PP & -0.123 & -0.047 & 1.058 & 0.683 \\
\hline & ADF & -0.539 & $-3.592^{\star \star \star}$ & -0.982 & $-3.717^{\star \star \star}$ \\
\hline & Kao (ADF) & $-2.753^{\star \star \star}$ & & & \\
\hline \multirow[t]{3}{*}{ Wf, Wt, Ic } & PP & 0.561 & 0.806 & -1.102 & -1.418 \\
\hline & ADF & -0.973 & $-2.317^{\star *}$ & $-3.513^{\star * *}$ & $-5.042^{\star * *}$ \\
\hline & Kao (ADF) & $-3.226^{* * *}$ & & & \\
\hline \multirow[t]{3}{*}{ Wf, Wt, Odr } & PP & 0.826 & 0.047 & 0.372 & $-2.546^{\star *}$ \\
\hline & ADF & -0.387 & $-5.653^{* * *}$ & $-2.147^{\star \star}$ & $-7.941^{* * *}$ \\
\hline & Kao (ADF) & $-3.577^{\star \star *}$ & & & \\
\hline \multirow[t]{3}{*}{ Wf, Wt, dr } & PP & 1.161 & 0.273 & 0.463 & $-3.626^{\star \star \star}$ \\
\hline & ADF & 0.616 & $-5.428^{\star \star *}$ & $-1.933^{*}$ & $-8.086^{\star * *}$ \\
\hline & Kao (ADF) & $-2.688^{* * *}$ & & & \\
\hline
\end{tabular}

Null hypothesis for all tests is No cointegration. The choice of the appropriate lag-lenghts for both the PP and the ADF statistics are made according to the Schwarz-Bayesan Information Criterion.

${ }^{*},{ }^{* *},{ }^{* \star *}$ significant at 10,5 and $1 \%$ respectively. The tests are one-sided and the statistics are normally distributed. 
Table 5. Long run household savings function: FMOLS cointegration estimates, 7 different models

\begin{tabular}{|l|ccc|ccc|}
\hline Models & \multicolumn{3}{|c|}{ Model with no time dummies } & \multicolumn{3}{|c|}{ Model with time dummies } \\
\hline 1 & $\mathrm{Wf}$ & $\mathrm{Wt}$ & & $\mathrm{Wf}$ & $\mathrm{Wt}$ & \\
& $-0.03^{* * *}$ & $-0.04^{* * *}$ & & -0.01 & $-0.08^{* * *}$ & \\
& $(-12.74)$ & $(-10.96)$ & & $(0.57)$ & $(-8.28)$ & \\
\hline 2 & $\mathrm{Wf}$ & $\mathrm{Wt}$ & $\mathrm{savg}$ & $\mathrm{Wf}$ & $\mathrm{Wt}$ & $\mathrm{savg}$ \\
& $-0.01^{* * *}$ & 0.01 & -0.19 & -0.06 & $-0.08^{* * *}$ & 0.67 \\
& $(-17.28)$ & $(1.21)$ & $(0.58)$ & $(-0.06)$ & $(-9.61)$ & $(-1.04)$ \\
\hline 3 & $\mathrm{Wf}$ & $\mathrm{Wt}$ & $\mathrm{dr}$ & $\mathrm{Wf}$ & $\mathrm{Wt}$ & $\mathrm{dr}$ \\
& $-0.00^{* * *}$ & $-0.16^{* * *}$ & $-7.58^{* * *}$ & $-0.01^{* * *}$ & $-0.06^{* * *}$ & $0.90^{* * *}$ \\
& $(-20.61)$ & $(-17.77)$ & $(-5.87)$ & $(7.64)$ & $(-2.51)$ & $(6.06)$ \\
\hline 4 & $\mathrm{Wf}$ & $\mathrm{Wt}$ & $\mathrm{odr}$ & $\mathrm{Wf}$ & $\mathrm{Wt}$ & $\mathrm{odr}$ \\
& $-0.06^{* * *}$ & $0.06^{* * *}$ & $-0.11^{* * *}$ & -0.00 & $-0.05^{* * *}$ & $6.22^{* * *}$ \\
& $(-18.27)$ & $(-2.71)$ & $(4.81)$ & $(-0.47)$ & $(-8.52)$ & $(-2.54)$ \\
\hline 5 & $\mathrm{Wf}$ & $\mathrm{Wt}$ & $\mathrm{infl}$ & $\mathrm{Wf}$ & $\mathrm{Wt}$ & $\mathrm{infl}$ \\
& $-0.04^{* * *}$ & $-0.04^{* * *}$ & $0.01^{* * *}$ & $0.00^{* * *}$ & $-0.11^{* * *}$ & -0.00 \\
& $(-20.89)$ & $(-9.32)$ & $(13.39)$ & $(-3.34)$ & $(-15.70)$ & $(0.31)$ \\
\hline 6 & $\mathrm{Wf}$ & $\mathrm{Wt}$ & $\mathrm{r}$ & $\mathrm{Wf}$ & $\mathrm{Wt}$ & $\mathrm{r}$ \\
& $-0.06^{* * *}$ & $0.26^{* * *}$ & $0.02^{* * *}$ & -0.01 & $-0.12^{* * *}$ & $-0.07^{* * *}$ \\
& $(-16.33)$ & $(16.33)$ & $(24.94)$ & $(-0.69)$ & $(-13.33)$ & $(-3.61)$ \\
\hline 7 & $\mathrm{Wf}$ & $\mathrm{Wt}$ & $\mathrm{lc}$ & $\mathrm{Wf}$ & $\mathrm{Wt}$ & $\mathrm{Ic}$ \\
& $-0.05^{* * *}$ & $-0.25^{* * *}$ & $-0.11^{* * *}$ & $-0.03^{* * *}$ & $-0.14^{* * *}$ & -0.00 \\
& $(4.79)$ & $(8.12)$ & $(-18.37)$ & $(-4.34)$ & $(-7.15)$ & $(-0.54)$ \\
\hline
\end{tabular}

t-values are in parenthesis; ${ }^{*},{ }^{* *},{ }^{* * *}$ significant at 10,5 and $1 \%$ respectively.

Table 6. Panel cointegration test results, wealth measures and additional explanatory variables

\begin{tabular}{|lc|c|c|c|c|}
\hline & Model & \multicolumn{2}{|c|}{ Within dimension } & \multicolumn{2}{c|}{ Between dimension } \\
& Specification & Intercept, & Intercept & Intercept, & Intercept \\
no trend & and trend & no trend & and trend \\
\hline Variables & Statistics & & & & \\
Wf, Wt, savg, odr & PP & 0.607 & -1.360 & $-3.494^{* * *}$ & $-3.434^{* * *}$ \\
& ADF & 0.640 & $-4.513^{* * *}$ & $-4.307^{* * *}$ & $-5.496^{* * *}$ \\
\hline Wf, Wt, savg, dr & PP & 2.735 & -0.219 & $-2.887^{* * *}$ & $-5.288^{* * *}$ \\
& ADF & 1.554 & $-2.307^{* *}$ & $-3.544^{* * *}$ & $-6.063^{* * *}$ \\
\hline
\end{tabular}

Null hypothesis for all tests is No cointegration. ${ }^{*},{ }^{* *},{ }^{* * *}$ significant at 10,5 and $1 \%$ respectively.

The tests are one-sided and the statistics are normally distributed. 
Table 7. Long run household savings function: FMOLS cointegration estimates, the final model

\begin{tabular}{|c|c|c|c|c|}
\hline \multirow{3}{*}{ Australia } & Wf & Wt & savg & $\mathrm{dr}$ \\
\hline & 0.01 & $-0.18^{* * *}$ & -0.19 & -0.40 \\
\hline & $(0.70)$ & $(-3.82)$ & $(-0.40)$ & $(-0.71)$ \\
\hline \multirow[t]{2}{*}{ Austria } & $-0.03^{* *}$ & $-0.04^{\star \star \star}$ & -0.03 & 0.54 \\
\hline & $(-2.20)$ & $(-3.35)$ & $(-0.18)$ & $(1.13)$ \\
\hline \multirow[t]{2}{*}{ Belgium } & $0.05^{\star *}$ & -0.01 & $0.60^{\star *}$ & 0.07 \\
\hline & (2.31) & $(-0.26)$ & $(1.98)$ & $(0.12)$ \\
\hline \multirow[t]{2}{*}{ Canada } & 0.02 & -0.05 & $-1.64^{\star \star \star}$ & $-1.37^{\star \star \star}$ \\
\hline & $(0.89)$ & $(-0.52)$ & $(-6.71)$ & $(-3.15)$ \\
\hline \multirow[t]{2}{*}{ Denmark } & $0.33^{* \star *}$ & $-0.20^{\star \star \star}$ & $-8.34^{* \star *}$ & $6.03^{* \star *}$ \\
\hline & (11.05) & $(-6.60)$ & $(-15.51)$ & $(-21.26)$ \\
\hline \multirow[t]{2}{*}{ Finland } & $-0.17^{* *}$ & 0.08 & $1.50^{* * *}$ & 2.74 \\
\hline & $(-2.54)$ & (1.07) & (3.22) & $(0.70)$ \\
\hline \multirow[t]{2}{*}{ France } & $-0.05^{* * *}$ & 0.04 & $-0.92^{* * *}$ & 0.51 \\
\hline & $(-2.85)$ & $(1.37)$ & $(-3.92)$ & $(1.25)$ \\
\hline \multirow[t]{2}{*}{ Germany } & $-0.02^{\star \star *}$ & $-0.08^{\star \star \star}$ & $0.19^{\star * *}$ & -0.14 \\
\hline & $(-4.12)$ & $(-5.93)$ & $(4.89)$ & $(-0.52)$ \\
\hline \multirow[t]{2}{*}{ Italy } & $-0.13^{\star \star \star}$ & $-0.05^{\star *}$ & $-1.45^{\star \star \star}$ & 0.24 \\
\hline & $(-7.75)$ & $(-2.19)$ & $(-9.37)$ & (1.57) \\
\hline \multirow[t]{2}{*}{ Japan } & -0.01 & $0.15^{* * *}$ & 0.06 & 0.37 \\
\hline & $(-1.02)$ & $(4.52)$ & $(0.49)$ & $(1.36)$ \\
\hline \multirow[t]{2}{*}{ Netherlands } & $0.02^{\star \star *}$ & 0.01 & $-0.99^{\star \star \star}$ & $-2.65^{\star \star *}$ \\
\hline & $(4.31)$ & $(0.16)$ & $(-3.11)$ & $(-2.66)$ \\
\hline \multirow[t]{2}{*}{ Norway } & $-0.03^{* *}$ & $-0.10^{* * *}$ & 0.21 & $-3.22^{* \star *}$ \\
\hline & $(-2.10)$ & $(-3.60)$ & $(1.61)$ & $(-3.44)$ \\
\hline \multirow[t]{2}{*}{ Portugal } & $0.05^{\star \star \star}$ & $0.09^{* * *}$ & $-0.68^{* * *}$ & $1.55^{\star \star *}$ \\
\hline & $(12.00)$ & $(3.28)$ & $(-14.54)$ & $(3.65)$ \\
\hline \multirow[t]{2}{*}{ Spain } & -0.00 & -0.00 & $-0.62^{* *}$ & $-0.36^{* * *}$ \\
\hline & $(-0.22)$ & $(-0.15)$ & $(-2.51)$ & $(-3.42)$ \\
\hline \multirow[t]{2}{*}{ Sweden } & 0.01 & $-0.45^{\star * *}$ & -0.30 & $-2.68^{* * *}$ \\
\hline & $(0.68)$ & $(-3.88)$ & $(-1.03)$ & $(-3.47)$ \\
\hline \multirow[t]{2}{*}{ Switzerland } & $0.02^{\star \star *}$ & $-0.17^{\star \star *}$ & $4.25^{\star \star \star}$ & $-8.82^{* * *}$ \\
\hline & $(5.28)$ & $(-8.73)$ & (22.79) & $(-5.73)$ \\
\hline \multirow[t]{2}{*}{ UK } & -0.01 & $-0.06^{* *}$ & $-0.18^{*}$ & 0.07 \\
\hline & $(-1.32)$ & $(-5.11)$ & $(-1.81)$ & $(0.51)$ \\
\hline \multirow[t]{2}{*}{ USA } & 0.02 & $0.23^{\star \star \star}$ & $-0.69^{* *}$ & $0.79^{\star \star *}$ \\
\hline & $(1.09)$ & $(5.19)$ & $(-2.14)$ & $(2.98)$ \\
\hline \multirow[t]{2}{*}{ Panel } & $0.00^{* \star \star}$ & $-0.04^{* * *}$ & $-0.51^{* \star *}$ & $-0.37^{\star * *}$ \\
\hline & (3.34) & $(-6.73)$ & $(-6.25)$ & (2.93) \\
\hline
\end{tabular}

t-values are in parenthesis; ${ }^{*},{ }^{* *},{ }^{* \star *}$ significant at 10,5 and $1 \%$ respectively.

Table A1. Correlation between Wt and the OECD Wt

\begin{tabular}{|l|c|}
\hline Country & Correlation \\
\hline Australia & $0.988^{\star \star *}$ \\
Canada & $0.747^{\star \star *}$ \\
France & $0.998^{\star \star *}$ \\
Germany & -0.042 \\
Italy & $0.813^{\star \star \star}$ \\
Japan & $0.895^{\star \star \star}$ \\
Sweden & $0.913^{\star * *}$ \\
United Kingdom & $0.943^{\star \star *}$ \\
United States of America & $0.925^{\star \star *}$ \\
\hline
\end{tabular}

${ }^{\star},{ }^{* \star},{ }^{\star \star *}$ significant at 10,5 and $1 \%$ respectively 